\title{
Is the good creation only provisional?
}

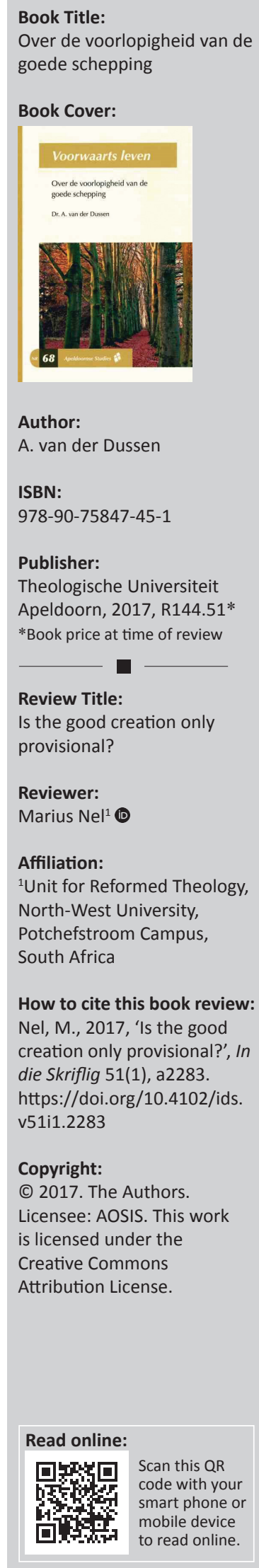

The book represents a paper read at the opening of the academic year of the Theologische Universiteit Apeldoorn on 5 September 2016. The issue under discussion is whether life after death will be better, richer and more glorious than life on earth that has in many instances been characterised as a vale of tears, or whether creation is now beautiful and already complete. Should Christians affirm creation, or denigrate it in gnostic fashion? This is in imitation of the counsel in 1 Corinthians 7:29-31 that states that the time is short; those who use the things in the world should use it as though they were not dependent on them as the world in its present form is passing away.

In reaction to Feuerbach's and Nietzsche's criticism of Christians' alienage in the present world, German liberal theologians like Albrecht Ritschl one-sidely emphasised the diesseitige Weltstellung des Menschen, avoiding any reference to eternal salvation. Later Dietrich Bonhoeffer also emphasises that the kingdom of God on earth should form the centre of Christians' interest, without denying that their fatherland is elsewhere. He does not deny the provisionality of God's good creation but he does not accentuate it. This also happened when reformed theology with a one-sided longing for heaven was corrected in neocalvinism with its interest in culture. Herman Bavinck celebrates Ritschl's aversion to abstract supranaturalism that limits salvation exclusively to the transcendent and adds that Christians should not flee the world but fulfil the will of the Father by faithfully living out their calling in the world. He criticises hostility towards the world as a result of a dualism between the supernatural and the natural, and recreatio versus nova creatio. Kuyper also warns against what he typifies as the anabaptist flight from the world, and adds that there is no inch width in the entirety of human life over which Christ as the Sovereign does not call: Mine! The sovereignty of Christ is also realised in increasing human scientific and technological control of nature, leading to Kuyper's appreciation of life on earth. At the same time, he does not deny the importance of hope for a future age but he interprets the Christian life as a pilgrimage where believers live more and more into the heavenly.

This is not the case with A.A. van Ruler who radically denies the provisionality of the good creation. He asserts that in his recreatio, God will work with the raw materials of this world. He suggests that the centre of gravity of the loci of dogmatics should be revisited, so that recreatio stands in service of creation, as the New Testament is to be understood in terms of the Old, the Messiah in terms of the kingdom of God, and the Christian gospel in terms of humanity. In his eschatology, this world is the actual and only world.

However, biblical proclamation relativises earthly reality with hope for the second coming of Christ resting on a new heaven and a new earth (2 Pt 3:13; Rv 21:1). While Van Ruler defines the 'new' in terms of restoration and renovation of the original, good creation, K. Schilder states that God has not created the world ready and done, but as a growth process with creation evolving in history. Paradise was the beginning of a world in hope that will find its completion in the new Jerusalem. Human beings are called to collaborate with God in the unfolding of creation; they should take out of the world all it contains. Even if the first human beings did not sin, he argues, the world would still have had a history that unfolds on its way to its realisation. The new world will be renewed in terms of its being saved from evil, and purified to completion. In the mean time, recreatio is already part of our world through the praesentia salutis of the incarnate Word that lived amongst human beings, and the Spirit that renews human beings through rebirth. Van Ruler has been criticised that his view of history is too optimistic because he takes sin too little into account.

Van der Dussen therefore looks to others to formulate a reformed vision on the good creation. Berkhof's starting point is Philippians 3:20-21 that states that believers' citizenship is in heaven from where they eagerly wait for their Saviour who will change their unassuming bodies and make them like his glorious body (cf. Jn 17:22; Rm 8:17-21; 2 Cor 3:18; 1 Jn 3:22). Christ is not so much to be confessed as Saviour of fallen humanity as the One who introduces a higher form of being human than was found in Adam before the fall (1 Pt 1:4). Creation is therefore a provisional form of realisation of being human. That will only be realised in its higher and definitive form 
when human beings and God are unified even more intimately than in the first creation of humanity. Berkouwer reacts to the idea that the incarnation is not only to be considered in terms of sin but that it will eventually contribute to human elevation or deification. He rejects the motive of elevation and rather speaks of restoratio of created beings. Bavinck agrees that the Word became flesh exclusively with the purpose that Christ died to reconcile human beings with God, but adds that his death brings about human beings' stabile and intimate fellowship with God.

The diversity of reformed opinions shows that ongoing reflection is necessary although they agree that the provisionality of creation should be discounted in all theological endeavours in one form or another. On the one hand it is important to remember that the world experiences continuous cultural and technical developments and that its definitive character has not realised as yet; on the other hand the expectation should be kept alive that an unparalleled glory awaits God's children in the new dispensation. The world will not only be saved from its infertility caused by human sin, but will also be transformed by and into God's glory. Eschatologically speaking, the perspective of the renewal and full deployment of life on earth is balanced with the longing of fellowship with God and his glory that will only fully realise with the homecoming in the new world. This double perspective stamps the current creation as provisional. Because earthly life will be crowned with unprecedented glory it is therefore necessary that humans live with full intensity in spite of its provisionality.

This short thesis may be valuable as an introduction to the theme of provisionality of creation. Due to its length (38 pp.) it, however, cannot further develop the different parts of the argument as fully as necessary to do justice to it. The result is that the eschatological viewpoint is narrowed down and the conclusion at the end of the book is not satisfactorily argued. More space is needed to present the full arguments of the different interlocutors of the author and it would have been preferable to use other viewpoints to contrast the issues under discussion.

For graduate theological students and believers who are interested in theology the book may serve as a first step to think about an element of eschatology that still has relevance for the church. These readers may hopefully be stimulated to consult the authors that are cited in order to broaden their knowledge of the complexity of different viewpoints found not only amongst theologians but also in the New Testament itself. 